\title{
A COMPREHENSIVE REVIEW OF SYSTEMIC FACTORS ASSOCIATED WITH PERI- IMPLANT DISEASES
}

\author{
Mohammed Alshehri ${ }^{1 a^{*}}$ \\ 1Dental Department, King Khalid University Hospital, King Saud University, Riyadh, Saudi Arabia
}

${ }^{a} B D S, A E G D$, SSC-ARD, SF-DI, Consultant in Cosmetic Restorative and Implant Dentistry

Received: February 01, 2017

Cite this article:

Alshehri M. A comprehensive review of systemic factors associated with periimplant diseases. Stoma Edu J. 2017;4(1):37-43.

\section{ABSTRACT}

DOI: 10.25241/stomaeduj.2017.4(1).art.3

Background: A variety of systemic factors have been associated with peri-implant diseases.

Objective: The aim of the present comprehensive review was to assess current literature regarding the systemic factors associated with the etiology of peri-implant diseases.

Results: Both normal and premalignant oral mucosa cells (NOK and POE9i) displayed uptake of PLGAChiNPs in a time and concentration-dependent manner, both in 2D and 3D models. A higher and more rapid uptake of PLGAChi NPs by precancerous cell line POE9i was observed when compared to NOKs. Interestingly, DPCs did not display internalized PLGAChi NPs, even at the highest concentration of $200 \mathrm{~g} / \mathrm{mL}$.

Data source: Databases were searched till January 2017 using different combinations of the following key words: "acquired immune deficiency syndrome"; "cancer"; "diabetes mellitus"; "genetic"; "periimplant diseases"; "peri-implantitis", "renal"; and "risk-factors".

Study selection: Clinical studies assessing the systemic factors associated with the etiology of periimplantitis were included. Letters to the Editor, case-reports, case-series, in-vitro studies, studies on animal models and commentaries were excluded.

Data extraction: The pattern of the present comprehensive review was customized to primarily summarize the pertinent information.

Data synthesis: Poorly-controlled diabetes mellitus (DM) is a significant risk factor for peri-implant diseases; however, under optimal glycemic control dental implants can osseointegrate in patients with DM. Osteoporosis and rheumatoid arthritis have been associated with peri-implant diseases; however, implant surface modifications and optimal oral hygiene maintenance are essential parameters that can facilitate osseointegration in these patients. Although irradiation is a significant risk-factor for peri-implant diseases; studies have shown that osseointegration and survival of implants is possible in cancer patients. There is a weak evidence that HIV infection is no more a contradiction for implant therapy. Although systemic diseases are significant risk-factors for dental implant failure, proper management of the systemic disorder and optimal oral hygiene may support osseointegration and survival of dental implants in medically-compromised patients.

Keywords: acquired immune deficiency syndrome, cancer, diabetes mellitus, genetic, peri-implant diseases.

\section{Introduction}

Although studies ${ }^{1-3}$ have reported implant success and survival rates of up to $100 \%$; a number of systemic factors have been reported to jeopardize the success and survival of dental implants. ${ }^{4,5}$ According to a consensus report from the 6th European Workshop on Periodontology, peri-implantitis is defined as the presence of inflammation of the peri-implant mucosa and concurrent loss of supporting alveolar bone. ${ }^{6}$

\section{*Corresponding author:}

Dr Mohammed Alshehri, BDS,AEGD, SSC-ARD, SF-DI, Dental Department, King Khalid, University Hospital, King Saud University, Riyadh, Saudi Arabia. Tel/Fax: +96.655.380.333/+966.114.672.428,e-mail:dr_mzs@hotmail.com 
Mombelli et al. ${ }^{7}$ described peri-implantitis as a sitespecific inflammatory condition, which displays clinical and radiographic features that are similar to those in patients with chronic periodontitis. Data regarding the prevalence of peri-implantitis is inconsistent. In the study by Koldsland et al., ${ }^{8}$ the prevalence of peri-implantitis ranged between $11.3 \%$ and $47.1 \%$; whereas Mombelli et al. ${ }^{9}$ reported peri-implantitis in $20 \%$ of their study population during 5 to 10 years of followup. In the study by Zitzmann and Berglundh, ${ }^{6}$ the frequency of peri-implantitis varied between $28 \%$ and at least $56 \%$ of the participants and $12 \%$ and $43 \%$ of individual implants. Peri-implant diseases are categorized into two types namely, peri-implant mucositis and peri-implantitis. Periimplant mucositis is characterized by inflammation of soft tissues around the implant without any signs of peri-implant alveolar bone loss.6 Patients with peri-implant mucositis exhibit bleeding on probing (BOP), peri-implant probing depth $\geq$ $4 \mathrm{~mm}$ and/or suppuration. ${ }^{10,11}$

A variety of factors, local as well as systemic factors have been associated with the etiology of peri-implantitis. ${ }^{12-16}$ It is well known that poor oral hygiene, tobacco smoking, poor bone quality and quantity, jaw location and bruxism are among the most common local factors associated with the etiology of peri-implantitis. Nevertheless, the contribution of systemic factors such as immunosuppression (as observed in patients with acquired immune deficiency syndrome, osteoporosis, poorly-controlled diabetes mellitus and cancer) and use of medications (such as bisphosphonates and corticosteroids) that have also been associated with the etiology of periimplantitis cannot be disregarded (Fig. 1). ${ }^{17-21}$ Considering the length of the article, the author dedicated the present article to comprehensively review the systemic risk-factors associated with the etiology of peri-implantitis. The aim of the present comprehensive review was to provide an overview of current literature regarding the systemic conditions associated with the etiology of peri-implantitis.

\section{Materials and methods \\ 2.1. Focused question}

The addressed focused question was "Which systemic conditions are associated with the etiology of peri-implant diseases?"

\subsection{Literature search strategy}

PubMed/Medline, Scopus, EMBASE, ISI Web of knowledge and Google-Scholar databases were searched from till January 2017 using the following key words: "arthritis", "cancer", "diabetes mellitus"; "acquired immune deficiency syndrome"; "renal disorders"; "osteoporosis", "peri-implant/ periimplant" and "genetics".

Clinical studies assessing the local risk-factors associated with the etiology of peri-implant diseases were included.

\subsection{Eligibility criteria}

Results from only clinical studies were included. Letters to the Editor, historic reviews, case-reports, case-series, in-vitro studies, studies on animal models and commentaries were excluded. The pattern of the present comprehensive review was customized to primarily summarize the pertinent information.

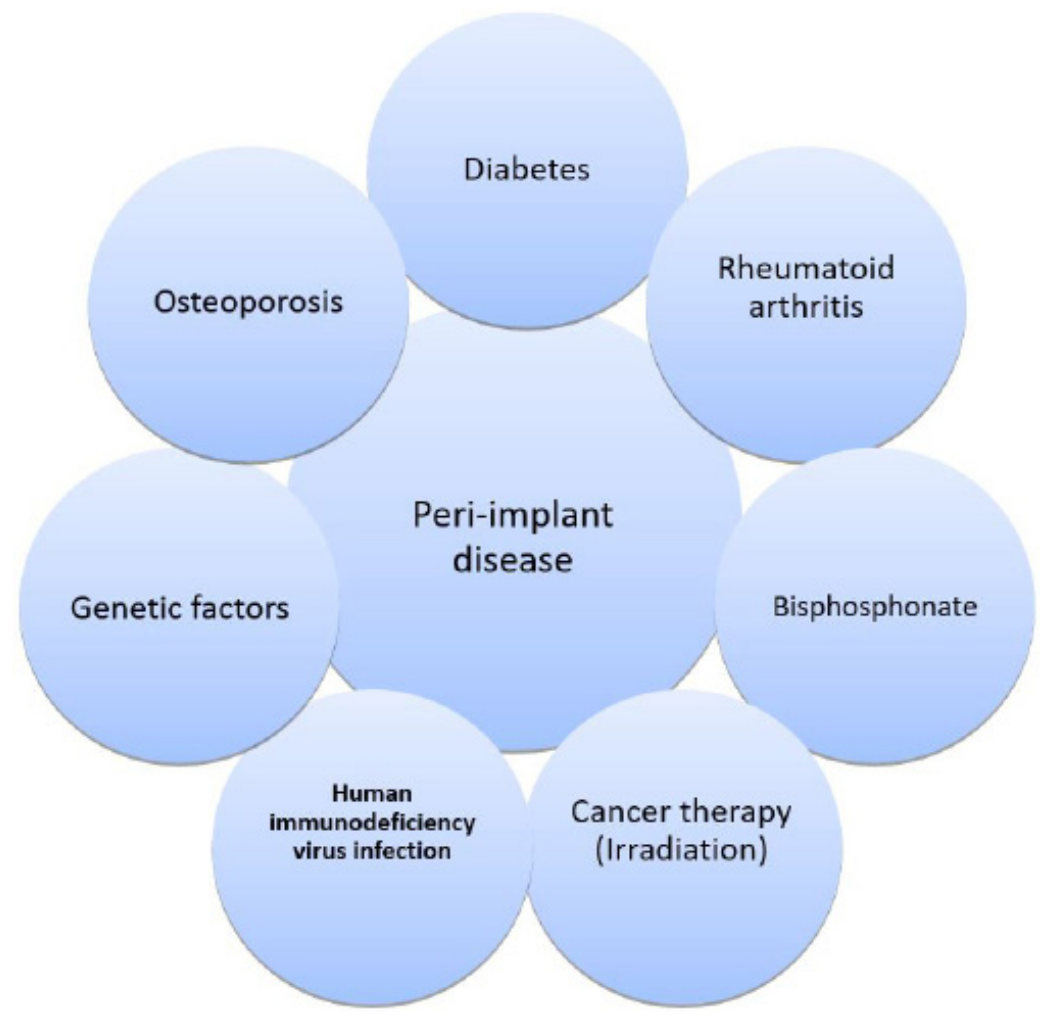

Figure 1. Systemic factors associated with peri-implant diseases. 


\section{Results}

\subsection{Diabetes mellitus}

Diabetes mellitus (or diabetes) is a common metabolic disorder characterized by hypergly-cemia due to impaired insulin secretion, insufficient insulin action, or both. ${ }^{22}$ The main types of diabetes include type 1 diabetes and type 2 diabetes. Type 1 diabetes is associated with pancreatic beta $(\beta)$-cell destruction and accounts for $5-10 \%$ of the subjects with diabetes. Type 2 diabetes is associated with a relative, rather than an absolute insulin deficiency and accounts for $90-95 \%$ of all individuals with diabetes. ${ }^{23}$ Individuals with poorly-controlled diabetes are more susceptible to develop complications after implant therapy compared to individuals with well-controlled diabetes. ${ }^{24}$

Chronic hyperglycemia has been related with tissue damage, since endothelial cells take up glucose passively in an insulin-independent manner. ${ }^{25,26}$ Hyperglycemia is also associated with an altered host resistance, for example, defective migration of polymorphonuclear leukocytes, impaired phagocytosis and an exaggerated inflammatory response to microbial products. ${ }^{27}$

The treatment of diabetes focuses on the attainment of an optimal glycemic control in order to impede complications.

Individuals with diabetes are more susceptible to periodontal disease, which is also recognized as the sixth complication of diabetes. ${ }^{28-32}$

The underlying pathophysiology that increases the risk of periodontal bone loss in subjects with diabetes is poorly understood; however it has been associated with the formation and accumulation of glucose-mediated advanced glycation end-products (AGEs).

AGEs accumulate in the plasma and tissues (including the periodontium) during the process of normal aging, but to an accelerated degree in subjects with diabetes. ${ }^{33}$ AGEs contribute to periodontal destruction by activating receptors called "Receptor for AGEs (RAGE)" located on the periodontium and by reducing the production of matrix proteins, such as collagen and osteocalcin by gingival and periodontal fibroblasts. ${ }^{34-38}$

It has been suggested that the pathogenesis of diabetes and its complications are associated with an increased RAGE expression. . $^{29,39}$

Other cell types with RAGE expression include glomerular epithelial cells (podocytes), endothelial cells, vascular smooth muscle cells, inflammatory mononuclear phagocytes and lymphocytes. ${ }^{39}$ Therefore, an impaired glycemic status may negatively affect the outcome of implant therapy. In a systematic review, Javed and Romanos ${ }^{19}$ reported that under optimal glycemia control, dental implants can osseointegrate and remain functionally stable over long durations in patients with diabetes.

\subsection{Bisphosphonates}

Bisphosphonates (BPs), (such as alendronate, risendronate, ibandronate, and clodronate) are important group of drugs used for the treatment of metabolic and oncologic pathologies involving the skeletal system. The mode of action of BPs depends on the drugs' chemical structure. The two main categories of BPs are the "non-nitrogen" and "nitrogen-containing" BPs. ${ }^{40}$ Non-nitrogencontaining BPs are metabolized rapidly, whereas nitrogen-containing BPs are much more potent and are not metabolized. ${ }^{41}$ These drugs act by inhibiting osteoclastic activity and inducing their apoptosis. ${ }^{18}$ BPs may be administered by either oral or intravenous routes. Oral BPs are used in the treatment of diseases such as osteoporosis and Pagets disease; while intravenous BPs are administered to patients with breast cancer, multiple myeloma, bone metastasis and malignant hypercalcemia. The chief complication observed in patients under either oral or intravenous BP therapy is osteonecrosis of the jaw (ONJ). ${ }^{42}$ It has been suggested that all patients under bisphosphonate therapy who are expected to receive dental implants should be informed of the possible risks of development of ONJ and consequent implant loss beforehand; and an informed-consent must be obtained prior to installation of dental implants in these individuals. ${ }^{14,15}$

Although, the risk of developing ONJ in patients using BPs is estimated to be minimal (approximately $0.09 \%$ ), there still exists a controversy over the placement of dental implants in patients treated with BPs. ${ }^{43}$ Results from case-reports ${ }^{44-47}$ have shown that dental implants can osseointegrate and remain functionally stable in patients under BP therapy. Similar results have been reported in retrospective studies. ${ }^{48,49}$ Results by Bell and Bell50 showed comparable implant survival rates between patients using BPs and controls, that is, $95 \%$ and $96.5 \%$ respectively. Brooks et al. ${ }^{47}$ placed 10 implants in a patient on bisphosphonate therapy out of which, 9 implants osseointegrated successfully giving a success rate of $90 \%$. Likewise, results from a case-report by Wang et al. ${ }^{44}$ also showed implant healing to be uneventful with no alterations in the healing process of dental implants in a patient using BPs. Fugazzotto et al. ${ }^{51}$ showed that a history of bisphosphonate therapy was not associated with the occurrence of ONJ following installation of immediately-loaded dental implants.

In their systematic review, Javed and Almas ${ }^{18}$ reported that the incidence of implant failure in patients taking BPs is minimal.

The authors also concluded that placement of dental implants in patients taking BPs can have a positive outcome. $^{18}$

\subsection{Osteoporosis and rheumatoid arthritis}

Osteoporosis is a metabolic disease of bone characterized by low bone mineral density (BMD) and reduced bone mass due to impaired bone metabolism and imbalanced osteoblastic and osteoclastic activities. ${ }^{52,53}$ In osteoporotic bone, osteoblasts demonstrate impaired proliferative, synthetic and reactive ability to cellular mediators. ${ }^{52,54,55}$

Underlying causes of osteoporosis include pre- and postmenopausal estrogen deficiency, excessive glucocorticoid intake, eating disorders such as anorexia nervosa and celiac disease. ${ }^{56,57}$ Although the bone quality and strength are compromised in osteoporotic patients; osteoporosis is not considered a contraindication for implant the-rapy. ${ }^{58,59}$ In a recent 
systematic review, Javed et al. ${ }^{60}$ assessed the effect of osteogenic coatings on the osseointegration of implants under induced osteoporotic conditions. Nearly $80 \%$ studies reported that osteogenic coatings around implant surfaces enhance bone formation, bone-to-implant contact $(\mathrm{BIC})$ and bone volume (BV) under osteoporosis-like conditions. This could possibly be accredited to the increase in surface roughness of the implant caused by osteogenic coatings, which facilitate the attachment of osteoprogenitor cells to the implant surface. Holahan et al. ${ }^{59}$ conducted a retrospective study to evaluate whether a diagnosis of osteoporosis affected the survival rate of osseointegrated dental implants. In this study ${ }^{59}$, a total of 3,224 implants placed in 746 female patients aged at least 50 years old at the time of implant placement were assessed. The results showed that patients with a diagnosis of osteoporosis or osteopenia were not significantly more likely to develop implant failure compared to those without such a diagnosis. ${ }^{59}$

Krennmair et al. ${ }^{61}$ evaluated the implant treat-ment outcomes for patients suffering from autoimmune rheumatoid arthritis (RA) with or without concomitant connective tissue diseases (CTD). In this study, ${ }^{61} 34$ female patients ( 25 iso-lated RA; nine RA+CTD) were included. At the mean duration of follow-up of nearly 46 month, all implants presented a survival rate of $100 \%$. In isolated RA patients, acceptable marginal bone loss (MBL) (mean: $2.1 \mathrm{~mm}$; SD: $0.5 \mathrm{~mm}$ ), pocket depth (mean: $2.8 \mathrm{~mm}$; SD:3.2 mm) and healthy softtissue conditions (plaque/bleeding/gingiva index Grade 0 in 80\%) were observed. ${ }^{61}$ Results from a caseseries report, ${ }^{62}$ showed a high implant survival rate during follow-up with a cumulative 3-year implant success rate of $96.1 \%$. In this study, RA patients demonstrated acceptable MBL (mean: 2.1 +/- 0.5 $\mathrm{mm}$ ) and satisfactory soft tissue conditions; whereas CTD patients showed increased MBL (mean: 3.1 +/$0.7 \mathrm{~mm}$ ).

The study ${ }^{62}$ concluded that a high implant and prosthodontic success rate can be anticipated in patients suffering from RA; however, the authors emphasized that optimal oral hygiene assists in ensuring stable long-term survival of dental implants in patients with RA. ${ }^{62}$

\subsection{Irradiation}

Osteoradionecrosis is usually observed several years following radiotherapy and is associated with local trauma within the hypovascular-hypocellular hypoxic tissues (that occurs as a result of radiationinduced endarteritris). ${ }^{63}$ In this regard, the interval between the end of cancer therapy and placement of dental implants may contribute to the success or failure of osseointegration. Studies ${ }^{64-66}$ have investigated the required time interval between radiotherapy and implant installation that may influence osseointegration; however the results remain debatable. In a systematic review, Zen Filho et al. ${ }^{67}$ assessed the safety of dental implants placed in irradiated bone and to discuss their viability when placed post-radiotherapy. Eight publications were assessed in this systematic review ${ }^{67}$ and the results showed a total of 331 patients received 1237 implants. The time interval between irradiation and dental implantation ranged from 6 to 15 months. The overall implant failure rate of $9.53 \%$ and osseointegration success rates ranged between $62.5 \%$ and $100 \% .{ }^{67}$ In another review, Javed et al. ${ }^{20}$ assessed the implant survival rate after oral cancer therapy. In total, 21 studies were included in this review out of which, 16 studies reported that dental implants can osseointegrate and remain functionally stable in patients having undergone radiotherapy following oral cancer surgery. ${ }^{20}$ The authors concluded that dental implants can osseointegrate and remain functionally stable in patients having undergone oral cancer treatment. ${ }^{20}$

\subsection{Human immunodeficiency virus infection}

Human immunodeficiency virus (HIV) infection is characterized by progressive immune system failure that gives rise to the development of opportunistic infections and neoplasms. The virus invades CD4+ $T$ lymphocytes, macrophages and dendritic cells, and the CD4+ T cell counts gradually decrease as a result of direct cytopathic action or cytotoxic CD8+T lymphocyte-mediated attack. In a recent systematic review, Ata-Ali et al. ${ }^{68}$ attempted to answer the following focused question "does HIV infection have an impact upon dental implant osseointegration?" The combinations of search terms resulted in a list of 132 titles. Consequently, 101 studies were excluded on the basis of the evaluation of the title and abstract, thereby leaving 9 articles for eligibility assessment. Amongst the studies included in this systematic review, a total of 173 dental implants were placed in 80 patients ( 135 implants in 56 HIV-positive individuals and 38 implants in 24 HIV-negative patients -control groups). A single loss of dental implant osseointegration was recorded in an HIVpositive patient. ${ }^{68}$ In the study by Stevenson et al. ${ }^{69}$, 40 dental implants were placed in 20 HIV-infected patients. No implant osseointegration failures were recorded after 6 months of follow-up. Similarly, in another study of 39 dental implants placed in 24 HIV-infected patients, no implant osseointegration failures were recorded after 12 months of followup. ${ }^{70}$ Should dental implants placed in HIV positive patients sustain bone levels in the long-term (5 years or longer) requires further investigations.

\subsection{Genetic factors}

Jacobi-Gresser et al. ${ }^{71}$ assessed diagnostic markers to predict titanium implant failure.

The study reported that tumor necrosis factor-alpha (TNF- $\alpha$ ) and interleukin 1-beta (IL-1 $\beta$ ) release on titanium stimulation were significantly higher among patients with implant failure.

The results showed that IL-1 $1 \beta / \mathrm{TNF}-\alpha$ release and number of risk genotypes were significantly associated with implant failure. ${ }^{71}$

Vaz et al. ${ }^{72}$ examined IL-1 gene clusters in 155 patients with 100 successful implants and 55 unsuccessful implants.

The authors concluded that successful implants were associated with a negative genetic test and that unsuccessful implants were associated with a positive genetic test. ${ }^{72}$

Casado and colleagues reported that the IL-6 genotype was 1.53 times more likely to convey periimplant disease if the individuals had the GC 
genotype and allele G.

\section{Conclusion}

Although systemic diseases such as poorly controlled DM, RA and osteoporosis are significant risk-factors for dental implant failure, proper management of the systemic disorder and optimal oral hygiene may support osseointegration and survival of dental implants in medically-compromised patients.

\section{Conflict of interest and financial disclosure}

The author reports no conflict of interest and there was no external source of funding for the present study.

\section{References}

1. Carames J, Tovar Suinaga L, Yu Yc, Perez A, Kang M. Clinical advantages and limitations of monolithic zirconia restorations full arch implant supported reconstruction: case series. Int J Dent. 2015;2015:392496. doi: $10.1155 / 2015 / 392496$.

[Full text links] [Free PMC Article] [PubMed] Google Scholar (16) Scopus (10)

2. Fenner $N$, Hämmerle Ch, Sailer I, Jung Re. Long-Term Clinical, Technical, And Esthetic Outcomes Of All-Ceramic Vs. Titanium Abutments On Implant Supporting Single-Tooth Reconstructions After At Least 5 Years. Clin Oral Implants Res. 2016;27(6):716-723 doi: 10.1111/clr.12654 [Full text links] [PubMed] Google Scholar (15) Scopus (5)

3. Jeong MA, Jung MK, Kim SG, Oh JS. Implant stability measurements in the long-term follow-up of dentis implants: a retrospective study with Periotest. Implant Dent. 2015;24(3):263-266. doi: 10.1097/ld.0000000000000239. [Full text links] [PubMed] Google Scholar (4) Scopus (2)

4. Romanos GE, Javed F, Delgado-Ruiz RA, Calvo-Guirado JL Peri-implant diseases: a review of treatment interventions. Dent Clin North Am. 2015;59(1):157-178. doi: 10.1016/j. cden.2014.08.002

[Full text links] [PubMed] Google Scholar (39) Scopus (20)

5. Tonetti MS. Risk factors for osseodisintegration. Periodontol 2000. 1998:17:55-62.

[Full text links] [PubMed] Google Scholar (144) Scopus (74)

6. Zitzmann NU, Berglundh T. Definition and prevalence of peri-implant diseases. J Clin Periodontol. 2008;35(8 Suppl):286-291. doi: 10.1111/j.1600-051x.2008.01274.x. Review.

[Full text links] [PubMed] Google Scholar (854) Scopus (468)

7. Mombelli A, van Oosten MA, Schurch E, Jr., Land NP. The microbiota associated with successful or failing osseointegrated titanium implants. Oral Microbiol Immunol. 1987;2(4):145-151.

[Full text links] [PubMed] Google Scholar (1713) Scopus (1035)

8. Koldsland OC, Scheie AA, Aass AM. Prevalence of periimplantitis related to severity of the disease with different degrees of bone loss. J Periodontol. 2010;81(2):231-238. doi: 10.1902/jop.2009.090269. [Full text links] [PubMed] Google Scholar (298) Scopus (161)

9. Mombelli A, Müller N, Cionca N. The epidemiology of periimplantitis. Clin Oral Implants Res. 2012;23 Suppl 6:67-76. doi: 10.1111/j.1600-0501.2012.02541.x. Review. [Full text links] [PubMed] Google Scholar (347) Scopus (192)

10. Khammissa RA, Feller L, Meyerov R, Lemmer J. Peri-implant mucositis and peri-implantitis: clinical and histopathological characteristics and treatment. SADJ. 2012;67(3):122, 124 126. Review.

[PubMed] Google Scholar (30) Scopus (13)

11. Jankovic S, Aleksic Z, Dimitrijevic B, et al. Prevalence of human cytomegalovirus and Epstein-Barr virus in subgingival plaque at peri-implantitis, mucositis and healthy sites. A pilot study. Int J Oral Maxillofac Surg. 2011;40(3):271 276. doi: 10.1016/j.ijom.2010.11.004 [Full text links] [PubMed] Google Scholar (23) Scopus (14)

12. Tsigarida AA, Dabdoub SM, Nagaraja HN, Kumar PS. The influence of smoking on the peri-implant microbiome. J Dent Res. 2015;94(9):1202-1217. doi: 10.1177/0022034515590581.

[Full text links] [Free PMC Article] [PubMed] Google Scholar (24) Scopus (18)

13. Ferreira SD, Silva GL, Cortelli JR, Costa JE, Costa FO. Prevalence and risk variables for peri-implant disease in Brazilian subjects. J Clin Periodontol. 2006;33(12):929-935. doi: 10.1111/j.1600-051x.2006.01001.x.

[Full text links] [PubMed] Google Scholar (363) Scopus (168)

14. Degidi M, Nardi D, Piattelli A. 10-year prospective cohor follow-up of immediately restored XiVE implants. Clin Oral Implants Res. 2016 Jun;27(6):694-700. doi: 10.1111/ clr.12642.

[Full text links] [PubMed] Google Scholar (12) Scopus (4)

15. Miyata T, Kobayashi Y, Araki H, Ohto T, Shin K. The influence of controlled occlusal overload on peri-implant tissue. Part 3: a histologic study in monkeys. Int J Oral Maxillofac Implants.
2000;15(3):425-431.

[PubMed] Google Scholar (225) Scopus (117)

16. Wahlström M, Sagulin GB, Jansson LE. Clinical follow-up of unilateral, fixed dental prosthesis on maxillary implants. Clin Oral Implants Res. 2010;21(11):1294-1300

[PubMed] Google Scholar (34) Scopus (19)

17. Vohra F, Al-Rifaiy MQ, Almas K, Javed F. Efficacy of systemic bisphosphonate delivery on osseointegration of implants under osteoporotic conditions: lessons from animal studies. Arch Oral Biol. 2014;59(9):912-920. doi: 10.1016/j. archoralbio.2014.05.016.

[Full text links] [PubMed] Google Scholar (21) Scopus (10)

18. Javed F, Almas K. Osseointegration of dental implants in patients undergoing bisphosphonate treatment: a literature review. J Periodontol. 2010;81(4):479-484.doi: 10.1902/ jop.2009.090587.

[Full text links] [PubMed] Google Scholar (92) Scopus (53)

19. Javed F, Romanos GE. Impact of diabetes mellitus and glycemic control on the osseointegration of dental implants: a systematic literature review. J Periodontol. 2009;80(11):1719-1730. doi: 10.1902/jop.2009.090283 [Full text links] [PubMed] Google Scholar (225) Scopus (132)

20. Javed F, Al-Hezaimi K, Al-Rasheed A, Almas K, Romanos GE. Implant survival rate after oral cancer therapy: a review. Oral Oncol. 2010;46(12):854-859. doi: 10.1016/j. oraloncology.2010.10.004.

[Full text links] [Free PMC Article] [PubMed] Google Scholar (63) Scopus (37)

21. Lu SY, Huang CC. Resolution of an active periimplantitis in a chronic steroid user by bone augmentation with PepGen P-15 and a barrier membrane. J Oral Implantol. 2007;33(5):280-287. doi 10.1563/1548-1336(2007)33[280:ROAAPI]2.0.CO;2. [Full text links] [PubMed] Google Scholar (12) Scopus (3)

22. Classification and diagnosis of diabetes. Diabetes Care. 2015;38 Suppl S8-S16. doi: 10.2337/dc15-s005. [Full text links] [PubMed] Google Scholar (778) Scopus (476)

23. Diagnosis and classification of diabetes mellitus. Diabetes Care. 2005;28 Suppl 1:S37-S42. https://doi.org/10.2337/ diacare.28.suppl_1.S37

[Full text links] [PubMed] Google Scholar (13301) Scopus (806)

24. Fiorellini JP, Chen PK, Nevins M, Nevins ML. A retrospective study of dental implants in diabetic patients. Int J Periodontics Restorative Dent. 2000;20(4):366-373 [PubMed] Google Scholar (199) Scopus (97)

25. Ceriello A, Motz E. Is oxidative stress the pathogenic mechanism underlying insulin resistance, diabetes, and cardiovascular disease? The common soil hypothesis revisited. Arterioscler Thromb Vasc Biol. 2004;24(5):816-823. doi: 10.1161/01.ATV.0000122852.22604.78. Review. [Full text links] [Free article] [PubMed] Google Scholar (1364)

26. Zhang Y, Qu Y, Niu T, Wang H, Liu K. O-GlcNAc modification of Sp1 mediates hyperglycaemia-induced ICAM-1 up-regulation in endothelial cells. Biochem Biophys Res Commun. 2017;484(1):79-84. doi: 10.1016/j. bbrc.2017.01.068.

[Full text links] [PubMed] Google Scholar (0) Scopus (1)

27. Soory M. Hormone mediation of immune responses in the progression of diabetes, rheumatoid arthritis and periodontal diseases. Curr Drug Targets Immune Endocr Metabol Disord. 2002:2(1):13-25.

[PubMed] Google Scholar (53) Scopus (28)

28. Löe H. Periodontal disease. The sixth complication of diabetes mellitus. Diabetes Care. 1993;16(1):329-334. [PubMed] Google Scholar (1377) Scopus (638)

29. Lamster IB, Lalla E. Periodontal disease and diabetes mellitus: discussion, conclusions, and recommendations. Ann Periodontol. 2001;6(1):146-149. doi: 10.1902/ annals.2001.6.1.146 [PubMed] Google Scholar (62) Scopus (15)

30. Javed F, Näsström K, Benchimol D, et al. Comparison of periodontal and socioeconomic status between subjects with type 2 diabetes mellitus and non-diabetic controls. J Periodontol. 2007:78(11):2112-2119. doi: 10.1902 jop.2007.070186. 
[Full text links] [PubMed] Google Scholar (153) Scopus (105)

31. Javed F, Al Amri MD, Al-Kheraif AA, et al. Efficacy of nonsurgical periodontal therapy with adjunct Nd:YAG laser therapy in the treatment of periodontal inflammation among patients with and without type 2 diabetes mellitus: A shortterm pilot study. J Photochem Photobiol B. 2015;149:230234. doi: 10.1016/j.jphotobiol.2015.06.013. 234. doi: 10.1016/j.jphotobiol.2015.06.013.

32. Javed F, Al-Kheraif AA, Salazar-Lazo K, et al. Periodontal inflammatory conditions among smokers and neversmokers with and without type 2 diabetes mellitus. J Periodontol. 2015;86(7):839-846. doi: 10.1902/ jop.2015.150120.

[Full text links] [PubMed] Google Scholar (19) Scopus (14)

33. Wautier JL, Guillausseau PJ. Advanced glycation end products, their receptors and diabetic angiopathy. Diabetes Metab. 2001;27(5 Pt 1):535-542.

[Full text links] [PubMed] Google Scholar (324) Scopus (209)

34. Fong Y, Edelstein D, Wang EA, Brownlee M. Inhibition of matrix-induced bone differentiation by advanced glycation end-products in rats. Diabetologia. 1993;36(9):802-807. [PubMed] Google Scholar (35) Scopus (22)

35. Schmidt Am, Weidman E, Lalla E, et al. Advanced glycation endproducts (AGEs) induce oxidant stress in the gingiva: a potential mechanism underlying accelerated periodontal disease associated with diabetes. J Periodontal Res. 1996;31(7):508-515.

[Full text links] [PubMed] Google Scholar (289)

36. Lalla E, Lamster IB, Stern DM, Schmidt AM. Receptor for advanced glycation end products, inflammation, and accelerated periodontal disease in diabetes: mechanisms and insights into therapeutic modalities. Ann Periodontol. 2001;6(1):113-118. doi: 10.1902/annals.2001.6.1.113. [PubMed] Google Scholar (146) Scopus (81)

37. Oldfield MD, Bach LA, Forbes JM, et al. Advanced glycation end products cause epithelial-myofibroblast transdifferentiation via the receptor for advanced glycation end products (RAGE). J Clin Invest. 2001;108(12):18531863. doi: 10.1172/JCl11951

[Full text links] [Free PMC Article] [PubMed] Google Scholar (451)

38. Sajithlal G, Huttunen H, Rauvala H, Munch G. Receptor for advanced glycation end products plays a more important role in cellular survival than in neurite outgrowth during retinoic acid-induced differentiation of neuroblastoma cells. J Biol Chem. 2002;277(9):6888-6897. doi: 10.1074/jbc. M107627200.

[Full text links] [PubMed] Google Scholar (57) Scopus (43)

39. Kim W, Hudson BI, Moser B, et al. Receptor for advanced glycation end products and its ligands: a journey from the complications of diabetes to its pathogenesis. Ann NYAcad Sci. 2005:1043:553-561. doi: 10.1196/annals.1338.063 [Full text links] [PubMed] Google Scholar (101) Scopus (79)

40. Green JR. Bisphosphonates: preclinical review. Oncologist. 2004;9 Suppl 43-13. doi: 10.1634/theoncologist.9-90004-3. Review.

[Full text links] [PubMed] Google Scholar (440) Scopus (300)

41. Frith JC, Mönkkönen J, Blackburn GM, Russell RG, Rogers MJ. Clodronate and liposome-encapsulated clodronate are metabolized to a toxic atp analog, adenosine 5'-(beta, gamma-dichloromethylene) triphosphate, by mammalian cells in vitro. J Bone Miner Res. 1997;12(9):1358-1367. doi: 10.1359/jbmr.1997.12.9.1358.

[Full text links] [PubMed] Google Scholar (465)

42. Vahtsevanos K, Kyrgidis A, Verrou E, et al. Longitudinal cohort study of risk factors in cancer patients of bisphosphonaterelated osteonecrosis of the jaw. J Clin Oncol. 2009;27(32):5356-5362. doi: 10.1200/jco.2009.21.9584 [Full text links] [PubMed] Google Scholar (293) Scopus (197)

43. Sambrook P, Olver I, Goss A. Bisphosphonates and osteonecrosis of the jaw. Aust Fam Physician. 2006;35(10):801-803 [Full text links] [PubMed] Google Scholar (100) Scopus (74)

44. Wang HL, Weber D, Mccauley LK. Effect of long-term ora bisphosphonates on implant wound healing: literature review and a case report. J Periodontol. 2007;78(3):584-594. doi: 10.1902/jop.2007.060239. Review. [Full text links] [PubMed] Google Scholar (173) Scopus (74)

45. Pirih FQ, Zablotsky M, Cordell K, Mccauley LK. Case report of implant placement in a patient with paget's disease on bisphosphonate therapy. J Mich Dent Assoc. 2009;91(5):38-43. [PubMed] Google Scholar (11) Scopus (5)

46. Torres J, Tamimi F, Garcia I, et al. Dental implants in a patient with Paget disease under bisphosphonate treatment: a case report. Oral Surg Oral Med Oral Pathol Oral Radiol Endod. 2009;107(3):387-392. doi: 10.1016/j.tripleo.2008.11.024. [Full text links] [PubMed] Google Scholar (23) Scopus (9)

47. Brooks JK, Gilson AJ, Sindler AJ, et al. Osteonecrosis of the jaws associated with use of risedronate: report of 2 new cases. Oral Surg Oral Med Oral Pathol Oral Radiol Endod.
2007;103(6):780-786. doi: 10.1016/j.tripleo.2006.10.010 [Full text links] [PubMed] Google Scholar (89) Scopus (57)

48. Tallarico M, Canullo L, Xhanari E, Meloni SM. Dental implants treatment outcomes in patient under active therapy with alendronate: 3-year follow-up results of a multicenter prospective observational study. Clin Oral Implants Res. 2016:27(8):943-949. doi: 10.1111/clr.12662 [Full text links] [PubMed] Google Scholar (9) Scopus (3)

49. Al-Sabbagh M, Robinson FG, Romanos G, Thomas MV. Osteoporosis and bisphosphonate-related osteonecrosis in a dental school implant patient population. Implant Dent. 2015:24(3):328-332. doi: 10.1097/id.0000000000000234. [Full text links] [PubMed] Google Scholar (8) Scopus (3)

50. Bell BM, Bell RE. Oral bisphosphonates and dental implants: a retrospective study. J Oral Maxillofac Surg. 2008;66(5):1022-1024. doi: 10.1016/j.joms.2007.12.040. [Full text links] [PubMed] Google Scholar (139) Scopus (73)

51. Fugazzotto PA, Lightfoot WS, Jaffin R, Kumar A. Implant placement with or without simultaneous tooth extraction in patients taking oral bisphosphonates: postoperative healing early follow-up, and the incidence of complications in two private practices. J Periodontol. 2007;78(9):1664-1669. doi: 10.1902/jop.2007.060514.

[Full text links] [PubMed] Google Scholar (137) Scopus (79)

52. Torricelli P Fini M Giavaresi G Giardino R. Human osteoblast cultures from osteoporotic and healthy bone: biochemical markers and cytokine expression in basal conditions and in response to 1,25(OH)2D3. Artif Cells Blood Substit Immobil Biotechnol. 2002;30(3):219-227.

[PubMed] Google Scholar (27)

53. NIH consensus development panel on osteoporosis prevention, diagnosis, and therapy, March 7-29, 2000 highlights of the conference. South Med J. 2001;94(6):569-573. [PubMed] Google Scholar (2) Scopus (178)

54. Wong MM, Rao LG, Ly H, et al. In vitro study of osteoblastic cells from patients with idiopathic osteoporosis and comparison with cells from non-osteoporotic controls. Osteoporos Int. 1994:4(1):21-31.

[PubMed] Google Scholar (49) Scopus (41)

55. Neidlinger-Wilke C, Stalla I, Claes L, et al. Human osteoblasts from younger normal and osteoporotic donors show differences in proliferation and TGF beta-release in response to cyclic strain. J Biomech. 1995;28(12):1411-1418. [Full text links] [PubMed] Google Scholar (115)

56. Abraham A, Cohen A, Shane E. Premenopausal bone health: osteoporosis in premenopausal women. Clin Obstet Gynecol. 2013:56(4):722-729.doi: 10.1097/ grf.0b013e3182a8ae55

[Full text links] [Free PMC Article] [PubMed] Google Scholar (12) Scopus (7)

57. Corina M, Vulpoi C, Brănişteanu D. Relationship between bone mineral density, weight, and estrogen levels in pre and postmenopausal women. Rev Med Chir Soc Med Nat lasi. 2012;116(4):946-950. [PubMed] Google Scholar (32) Scopus (13)

58. Erdoğan $O$, Shafer DM, Taxel $P$, Freilich MA. A review of the association between osteoporosis and alveolar ridge augmentation. Oral Surg Oral Med Oral Pathol Oral Radiol Endod. 2007;104(6):738 E731-713. doi: 10.1016/j. tripleo.2007.04.008. Review.

[Full text links] [PubMed] Google Scholar (70) Scopus (37)

59. Holahan CM, Koka S, Kennel KA et al. Effect of osteoporotic status on the survival of titanium dental implants. Int J Oral Maxillofac Implants. 2008;23(5):905-910. [PubMed] Google Scholar (99) Scopus (69)

60. Javed F, Vohra F, Zafar S, Almas K. Significance of osteogenic surface coatings on implants to enhance osseointegration under osteoporotic-like conditions. Implant Dent. 2014;23(6):679-686. doi: 10.1097/id.0000000000000161. [Full text links] [PubMed] Google Scholar (31) Scopus (22)

61. Krennmair G Seemann R, Piehslinger E. Dental implants in patients with rheumatoid arthritis: clinical outcome and periimplant findings. J Clin Periodontol. 2010;37(10):928-936. doi: 10.1111/j.1600-051x.2010.01606.x. [Full text links] [PubMed] Google Scholar (30) Scopus (14)

62. Weinlander M, Krennmair G, Piehslinger E. Implant prosthodontic rehabilitation of patients with rheumatic disorders: a case series report. Int J Prosthodont. 2010;23(1):22-28.

[PubMed] Google Scholar (16) Scopus (10)

63. Marx RE, Johnson RP. Studies in the radiobiology of osteoradionecrosis and their clinical significance. Oral Surg Oral Med Oral Pathol. 1987;64(4):379-390. [PubMed] Google Scholar (268) Scopus (399)

64. Schoen PJ Raghoebar GM, Bouma J, et al Prosthodontic rehabilitation of oral function in head-neck cancer patients with dental implants placed simultaneously during ablative tumour surgery: an assessment of treatment outcomes and quality of life. Int J Oral Maxillofac Surg. 2008;37(1):8-16. doi: 10.1016/j.ijom.2007.07.015. 
[Full text links] [PubMed] Google Scholar (88) Scopus (60)

65. Schoen PJ, Raghoebar GM, Bouma J, et al. Rehabilitation of oral function in head and neck cancer patients after radiotherapy with implant-retained dentures: effects of hyperbaric oxygen therapy. Oral Oncol. 2007;43(4):379-388. doi: 10.1016/j.oraloncology.2006.04.009.

[Full text links] [PubMed] Google Scholar (97) Scopus (63)

66. August M, Bast B, Jackson M, Perrott D. Use of the fixed mandibular implant in oral cancer patients: a retrospective study. J Oral Maxillofac Surg. 1998;56(3):297-301. [Full text links] [PubMed] Google Scholar (46) Scopus (33)

67. Zen Filho EV, Tolentino Ede S, Santos PS. Viability of dental implants in head and neck irradiated patients: a systematic review. Head Neck. 2016;38 Suppl 1:E2229-40. doi:

10.1002/hed.24098. Review.

[Full text links] [PubMed] Google Scholar (8) Scopus (5)

68. Ata-Ali J, Ata-Ali F, Di-Benedetto N, Bagán L, Bagán JV. Does HIV infection have an impact upon dental implant osseointegration? A systematic review. Med Oral Patol Oral Cir Bucal. 2015;20(3):E347-356. Review.

[Full text links] [Free PMC Article] [PubMed] Google Scholar (8)

69. Stevenson GC, Riano PC, Moretti AJ, et al. Short-term success of osseointegrated dental implants in HIV-positive individuals: a prospective study. J Contemp Dent Pract. 2007:8(1):1-10.

[PubMed] Google Scholar (37) Scopus (16)
70. Oliveira MA, Gallottini M, Pallos D, et al. The success of endosseous implants in human immunodeficiency viruspositive patients receiving antiretroviral therapy: a pilot study J Am Dent Assoc. 2011;142(9):1010-1016

[Full text links] [PubMed] Google Scholar (28) Scopus (19)

71. Jacobi-Gresser E, Huesker K, Schütt S. Genetic and immunological markers predict titanium implant failure: a retrospective study. Int J Oral Maxillofac Surg. 2013;42(4):537-543. doi: 10.1016/j.ijom.2012.07.018. [Full text links] [PubMed] Google Scholar (47) Scopus (22)

72. Vaz P, Gallas MM, Braga AC, et al. IL1 gene polymorphisms and unsuccessful dental implants. Clin Oral Implants Res. 2012;23(12):1404-1413. doi: 10.1111/j.16000501.2011.02322.x.

[Full text links] [PubMed] Google Scholar (25) Scopus (15)

73. Casado PL, Villas-Boas R, De Mello W, Duarte ME, Granjeiro JM. Peri-implant disease and chronic periodontitis: is interleukin-6 gene promoter polymorphism the common risk factor in a Brazilian population? Int J Oral Maxillofac Implants. 2013;28(1):35-43 .doi: 10.11607/jomi.2867. [PubMed] Google Scholar (21)

\section{Mohammed ALSHEHRI}

BDS, AEGD, SSC-ARD, SF-DI

Dental Department, King Khalid

University Hospital King Saud

University, Riyadh, Saudi Arabia

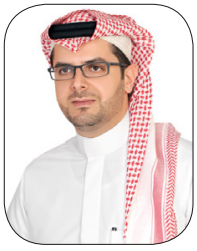

Dr Alshehri graduated from the College of Dentistry, King Saud University in 2001. Academically, he has acquired a Certificate in Advanced Education in General Dentistry at the University of Southern California, School of Dentistry. Thereafter, Dr Alshehri joined the SBARD Program wherein he obtained the Saudi Specialty Certificate in Advanced Restorative Dentistry. Subsequently, he was able to obtain a Certificate for Saudi Fellowship in Dental Implant and is currently a Fellow of International Team for Implantology (ITI). Professionally, Dr Alshehri has conducted multiple research projects, has obtained a number of patents and has made local and international presentations. Currently, Dr Alshehri is a Consultant in Cosmetic, restorative and implant dentistry at College of Medicine and University Hospitals and board member of the Saudi Dental Society.

\section{Osteoradionecrosis is usually observed several years following radiotherapy; and is associated with local trauma within the hypovascular-hypocellular hypoxic tissues.}
a. The first statement is true but the second statement is false;
b. The first statement is false but the second statement is true;
$\square$ c. Both statements are true;
d. Both statements are false.

\section{Osteoporosis is a metabolic disease of bone characterized by:}

a. low bone mineral density;

b. reduced bone mass due to impaired bone metabolism;

c. imbalanced osteoblastic activity;

d. all of the above.

\section{The mode of action of bisphosphonates depends on the drugs':}

a. Physical structure;

b. Chemical structure;

c. Half-life:

d. Side-effects.

\section{a. Implant diameter: \\ b. Tobacco smoking; \\ a c. Poor bone quality \\ d. Quantity of bone.}

All of the following are local risk-factors of peri-implant diseases EXCEPT: 